UNIVERSITA’ DEGLI STUDI DI BERGAMO

DIPARTIMENTO DI INGEGNERIA GESTIONALE

QUADERNI DEL DIPARTIMENTO $^{\dagger}$

Department of Economics and Technology Management

Working Paper

n. $08-2009$

Value determinants in the aviation industry

by

Paolo Malighetti, Michele Meoli, Stefano Paleari, Renato Redondi

† Il Dipartimento ottempera agli obblighi previsti dall’art. 1 del D.L.L. 31.8.1945, n. 660 e successive modificazioni. 


\section{COMITATO DI REDAZIONE ${ }^{\S}$}

Lucio Cassia, Gianmaria Martini, Stefano Paleari, Andrea Salanti

\footnotetext{
${ }^{\S}$ L'accesso alla Collana dei Quaderni del Dipartimento di Ingegneria Gestionale è approvato dal Comitato di Redazione. I Working Papers della Collana costituiscono un servizio atto a fornire la tempestiva divulgazione dei risultati dell'attività di ricerca, siano essi in forma provvisoria o definitiva.
} 


\title{
Value determinants in the aviation industry ${ }^{*}$
}

\section{Paolo Malighetti, ${ }^{\text {a }}$ Michele Meoli, ${ }^{\text {s }}$ Stefano Paleari, ${ }^{\text {a b }}$ Renato Redondi ${ }^{\mathrm{c}}$}

\author{
${ }^{a}$ University of Bergamo, viale G. Marconi, 5, 24044 Dalmine (BG), Italy \\ ${ }^{b}$ Scientific Director of the ICCSAI ( International Center for Competitiveness Studies in the Aviation Industry), \\ via Aeroporto, 13, 24050, Orio al Serio (BG), Italy \\ ${ }^{c}$ University of Brescia, via Branze, 38, 25123 Brescia (BS), Italy \\ § Contact author: Tel: +39 035 2052352; Fax: +39 035 2052077; email: michele.meoli@unibg.it
}

\begin{abstract}
This paper analyzes the value determinants for both airports and airlines. The analysis is based on a sample of 24 airport operators and 87 airlines listed on international financial markets on 31 December 2007. We analyse the value drivers for both airlines and airports by studying the determinants of the Tobin's Q. On average airport operators have a market valuation higher than carriers. On the whole sample we show that ownership concentration has a positive impact, while size and state ownership are, on average, detrimental for the market valuation. Further, other industry specific variables are statistically significant. Airport valuation is positively influenced by size, return on assets and the growth in terms of number of passengers. Airlines valuation is statistically higher for low-cost companies, while age and route number have a negative impact on market valuation.
\end{abstract}

Keywords: airlines; airports; valuation; value drivers

\footnotetext{
* We wish to thank all the participants in seminars at the University of Bergamo, at the Cranfield University, at the 13th ATRS World Conference 2009 (Abu Dhabi, UAE, 27 - 30 June 2009) for their comments. We are particularly grateful to Peter Morrell for detailed and extremely helpful comments on an earlier draft of the paper. Mauro Marchese and Alessandra Vedovati provided superb research assistance. Any errors are our own.
} 


\section{Introduction}

The industry of air transportation is currently attracting the attention of industrial and financial economists, because of the many changes that reshaped it in the last years, in particular the deregulation process, the opening of new airports and the increase in the number or scheduled routes, determinants of an increased competition and of the development of low-cost carriers. Contemporaneously, in the last decade the number of Airlines listed on financial markets around the world has progressively rose up to 87 at the end of 2007; at the same date, notwithstanding a longer and more complex privatization process, 24 companies managing airports were listed on various stock exchanges.

As these companies stopped relying on public financing and started recurring to the stock markets to support their activities, the financial research on stock returns, cost of capital, and asset valuation has become crucial for the application in the aviation industry. Indeed, these three topics are tightly intertwined. In this context, our paper contributes to the research on the aviation industry by analyzing what are the value determinants, for both airports and airlines companies. As an innovative methodological contribution, the analysis is here presented both at an industry level, summing up the two main components of the aviation industry, and at the sub-industry level, where airports and airlines are separately considered. While interesting also for researchers in financial economics and aviation industry, this research is primarily targeted to financial managers interested in a better understanding of the factors driving the market valuation of aviation companies.

In our analysis we make reference to the seminal contribution of Rappaport (1986), introducing the so-called Shareholder Value Analysis (SVA), and based on the identification of asset value drivers. As far as the aviation industry is concerned, notwithstanding its relevance in current economies, there is a lack of former research on the topic of firm valuation. Li et al. (2004), with reference to a sample of Airlines, report a weak relationship between Tobin's $\mathrm{Q}$ and a set of accounting variables, while the evolutionary setting and the global economic context seem to be the more significant value drivers. This paper aims to extend this analysis to both airports and airlines, widening the set of value drivers considered. In particular, we take into consideration four classes of determinants: financial information, ownership structure, industry variables and control variables.

The reminder of this paper is organized as follows. Section 2 provides a summary of previous literature on the topic of value determinants. Section 3 briefly describes our methodology. 
Section 4 presents the data. Section 5 reports evidence on value determinants. Section 6 concludes.

\section{Literature review}

The theoretical literature on firm valuation asserts that the market values of companies differ from their book values by the present value of their future abnormal earnings. With this respect, measures such as the market-to-book ratio (M/B), or the Tobin's $\mathrm{Q}$, should reflect investors' assessment of the future abnormal profits of the firm or, in other words, the difference between expected return on equity and cost of equity. These measures are of particular interest as they seem to generate a market premium. Indeed, the spread in returns between value stocks (those with low $\mathrm{M} / \mathrm{B}$ ) and growth stocks (those with high $\mathrm{M} / \mathrm{B}$ ) is found to be statistically and economically significant. Several explanations for this premium are possible. The most important are the risk proxy idea (Fama and French, 1992, 1993) and the investor overreaction idea (Lakonishok et al., 1994). The first explanation states that growth stocks are riskier and thus require a higher return. The second explanation posits that the premium arises because investors' expectations are based on extrapolation of recent past performance.

The extent of M/B and Tobin's Q may also be used as an indication of intangible assets of a company that are not entirely reflected in its financial statements. Financial accounting does not attempt to value the firm in its entirety since it records each of its severable assets at an amount in accordance with current legislation. On the other hand, the market values the company as a going concern. So, the valuation measures give an idea of the intellectual capital and intangibles not explicated from the financial accounting standards. However, the market value of a company is subject to a number of external variables, referring to degree of competition in the industry (monopoly power, deregulation) and to the investors' sentiment (think for instance to the overpricing of dotcoms going public on the new stock markets and the subsequent drop in their values).

Notwithstanding the important changes in air transportation and the increasing presence in the stock markets, the financial literature has not yet focused its attention on the valuation of companies belonging to this industry. Specifically, with regards to Airports, the most of the literature deals with operating efficiency and quality (see, for instance, Sarkis and Talluri, 2004; Vasigh and Haririan, 2003). On the topic of valuation, the most relevant contribution is that of Vasigh et al. (2003): the paper applies a discounted cash flows methodology to the 
three major Korean airports in terms of passengers, estimate a comprehensive value of 1.8 billion dollars, and then contrast it with the prices observed in actual transactions.

Greater attention has been dedicated to the segment of airlines, probably because of their anticipated recur to the financial markets with respect to Airports. According to Morrell (1997), further to the traditional fixed assets included in the balance sheets, two categories of intangible assets need to be considered in the case of Airlines: rights to fly a certain route (traffic rights), and rights to take off and land at a certain airport (rights to airport slots). Traffic rights value depends on route characteristics, competition and regulation aspects, management ability to build up a profitable network by combining the available routes, and other components eventually attached. Rights to airport slots are valued according to the airport congestion level. Currently slots are allocated to Airlines by the so-called grandfather rule, so that a carrier is usually allowed to use the same slots already employed in former periods. This process is strongly relevant for the valuation, because in Europe and many other countries slots can be exchanged, but not freely traded. In these regards, Tsai et al. (2008), by making use of event-study methodology, assess how a new route announcement affects an airline's stock market value, and verify that route strategy and entry strategy contribute to the direction and magnitude of the stock market reaction. With regards to the determinants of value, Li et al. (2004) analyze 27 European, American and Asian Airlines by studying their Tobin's Q over the period 1989-1999. First, they show that Tobin's Q is usually very low in the aviation industry, lower than 1 in most cases. Second, they report evidence of weak correlation with variables as the EBITDA Margin, performance ratios, sales to fixed assets and capital expenditure to fixed assets ratios. By contrast, a stronger correlation is found with operating variables, as well as with aviation industry and global context indicators. Nevertheless, no general conclusion is drawn on what are the value determinants for Airlines, as only a single firm determinant, the passenger load factor, is significant in their analysis.

\section{Methodology}

In this section we propose our methodology for the analysis of value determinants in the Aviation industry. With reference to the year 2007, we run a cross-section analysis of Tobin's $\mathrm{Q}$ as a dependent variable measuring valuation, and a set of regressors with reference to four groups of variables: financial information, ownership structure, industry-specific variables and control variables. 
As far as the choice of the dependent variable is concerned, former literature (see for instance Gupta et al., 2006) recommend the recourse to a simplified Tobin's Q as a substitute of the market to book ratio. The two variables are strongly correlated in the industry, but the Tobin's $\mathrm{Q}$ avoids the dropping of companies with a negative market to book ratio (see Li et al., 2004). The Tobin's Q, firstly conceived in Tobin and Brainard (1968) and Tobin (1969), is defined as the ratio between the market value of a firm (its enterprise value, EV henceforth) and the replacement cost of its assets. In other words, the Tobin's Q equals the ratio between the value of the firm on the financial markets, and the value of the assets on the goods market. Analogously to the market to book ratio, the Tobin's $Q$ is often employed in economic research as a measure of intangible value. Nevertheless, the Q is often considered as a more reliable measure, because of its capacity to neutralize the effects of depreciation policies. A value of the $\mathrm{Q}$ greater than 1 signals a firm which value is higher than the summation of its fixed assets, where the difference is to be related to its intangibles (Bhardwaj et al., 1999). Further, when the replacement cost is lower than the market value, then the firm is fancying returns on investment higher than the average. In conclusion, firms with a $\mathrm{Q}$ higher than 1 efficiently employ their resources, and generate a greater value with respect to those with a $\mathrm{Q}$ lower than 1. Unfortunately, Tobin's Q needs a great amount of input data to be evaluated, concerning the replacement costs for all the fixed assets, so that its exact calculation is usually unfeasible. In these respects, Chung and Pruitt (1994) propose the following approximation.

$Q=\frac{M V+P S+N F P}{T A}$

Where $M V$ is the market value of the firm's voting capital, $P S$ is the market value of the firms' non-voting capital, NFP is the value of net debt (short and long term debt, less cash and equivalents), $T A$ is the book value of total assets. While this measure is very easy to be calculated, empirical study show that it is strongly correlated to the correct formulation, so that recent papers suggest its utilization (see for instance DaDalt et al., 2003). In our analysis we therefore employ Tobin's Q (2007 average) as a measure of firm value. We also run sensitivity analyses, by substituting our independent variable with alternative measures such as a 3-year average Tobin's Q and the Market to Book Ratio. Results are mainly unchanged, and all estimations are available on request.

As far as the dependent variables are concerned, with reference to former studies on the valuation at the time of IPO (Bartov et al., 2002; Gou et al., 2005), we classify the value 
drivers as financial information, non financial information, and control variables. Non financial information are further split into ownership structure information and industryspecific measures, to be employed only in the segment specific analysis. Figure 1 summarizes all value drivers employed in our analysis. Reference to former contributions, justifying the inclusion, and expected coefficient impact, according to former literature, are also provided.

\section{*** [Insert somewhere here Figure 1] ***}

Because of the relevant number of regressors employed in the multivariate analysis, we recur to the following algorithm for the model specification. First, we separately consider each group of variable, and choose the most parsimonious model by dropping all insignificant variable until the Akaike Information Criterion is maximized. Then we pool the four set of selected regressors and repeat the selection on the whole sample. The analysis is repeated on the whole sample of aviation companies (Airports and Airlines, dropping industry-specific information) and then separately on the two subsamples of Airports and Airlines. Therefore, the outcome of the above-mentioned algorithm consists of three different models of regression for the value drivers of Aviation companies, Airports and Airlines companies. The choice of the regressors in the three models is, indeed, different, due to the selection process. A thorough sensitivity analysis has been carried out on the three models in order to verify the robustness of the results. In particular, after terminating the above described selection process, we tested for the inclusion of other relevant variables, and for the interaction of all dummy variables with the other regressors. The results we report are unchanged under most specifications. All estimations are available on request.

\section{Data selection and descriptive statistics}

While air transportation is known since the beginning of the twentieth century, only in the last decade a number of companies has decided to go public. The highest number of listed companies belongs to the segments of Airports and Airlines, respectively represented by 24 and 87 companies listed worldwide. Because of the limited number of companies in the other segments, their presence in several industry chains, or their scarce representation in official stock markets, the analysis in this paper will be focused only on the segments of Airports and Airlines. 
The list of companies listed worldwide on 31 December 2007 has been obtained through Orbis, and integrated with data provided by Datamonitor, Infinancial (Reuters) and Lexis Nexis (Thomson Financial), as well as with each company's annual reports. This allowed to determine the business model and the revenue sources for all companies, even if included in a business group, and select those relating to the aviation industry. In particular, Airports have been identified as follows: companies with revenues coming from both aviation and nonaviation services, with the exclusion of companies mainly dealing with airport services, such as maintenance. Airlines have been identified under the following conditions: companies transporting mainly passengers, owning a fleet composed by airplanes, therefore excluding companies involved in delivery, full air cargo services, and helicopters. As far as holding companies are concerned, they have been included among Airports or Airlines when their prevalent activity is focused on airport management or air transport. Therefore, all investment companies with an undefined business focus have been dropped, even when they own shares in Airlines or Airports. In particular, all holding companies included in the sample are characterized by a minimum $80 \%$ share of their revenue related to the aviation industry. Two tables in the Appendix provide a complete description of the samples of Airports and Airlines analyzed in the paper.

In the next two tables (Table 1 and Table 2), we summarize a statistical description of the two samples.

First, in Table 1 we report average and median values of the three typical ratios employed in firm indirect valuation, i.e. the Market to Book ratio, the Tobin's Q and the Price to EBITDA ratio. Two evidences emerge at first sight: on the one hand, the multiplier takes higher values for airports than for airlines; on the other hand, the ratios take quite different values when we split the two samples according to size. In general, larger companies are less valued than companies belonging to the first, second and third quartiles, for both airports and airlines, considering the three multipliers, with the only exception of the Price to EBITDA ratio for airline companies. When focusing on small and middle-size company, no clear trend is evident, showing how it is necessary to address the issue through a multivariate analysis.

Second, in Table 2 we report a summary of descriptive statistics with regards to all the regressors considered in the following empirical analyses.

*** [Insert somewhere here Tables 1 and 2] *** 


\section{Empirical results}

\subsection{Aviation industry}

Table 3 reports the result of the value driver analysis referred to both Airports and Airlines. Tobin's Q, estimated on the year 2007, is calculated for 24 airports and 87 Airlines, and regressed by OLS against the set of variables described above.

\section{*** [Insert somewhere here Table 3] ***}

The results show that, considering the whole aviation industry, an high ownership concentration tends to positively impact on the firm valuation. By contrast, size and state ownership are negative determinants. The airport dummy, controlling for the difference in valuation with respect to airlines, signals a positive marginal effects for Airports.

As far as the ownership concentration is concerned, the positive sign reflects the expectations of former research (such as La Porta et al., 2002), stating that when a few shareholders tightly hold the control of a company, they better focus on value maximization. Further, being the Aviation industry a very dynamic industry, strategic decisions are to be taken with speed and decision, and this is more likely to be in a stable concentrated ownership framework. The negative sign of the dummy controlling for State ownership is not surprising, and coherent to former results provided by Pedersen and Thomsen (2003) and by Meoli et al. (2008). When the main shareholder is the state or another public entity, the market perceives that objectives differing from value maximization may be pursued by the management. Firm size coefficient is also negative: even though bigger companies obtain higher visibility, since their assets are generally more liquid and their operations more diversified, their valuation is negatively affected. Lastly, the higher valuation of Airports with respect to Airlines may be due to the different competition framework characterizing the two segments, as well as to the different role in the economic development of a country. At the best of our knowledge, this is the first empirical evidence of this difference in the valuation ratios of airports and airlines. Further, this result justifies the recourse to two separate analysis of the two segment of aviation industry, in order to identify what are the sources of this different valuation. 


\subsection{Airports}

As reported in Table 4, when Tobin's Q of all 24 airports in the sample is regressed against the whole set of determinants, the significant coefficients we obtain refer to Firm Size, ROA (Return on Assets), Leverage, Passenger Growth, and Firm Age. Notice that the Airportswithin-100-Km dummy and the Aviation Revenue share are not dropped in the most parsimonious model, although their coefficient is not statistically different than zero.

\section{*** [Insert somewhere here Table 4] ***}

While the coefficients of ROA and traffic growth are of immediate interpretation, an insight on the other results seems appropriated. In contrast with former literature (such as Frank and Goyal, 2004), the leverage is a positive determinant of value for Airports. This result can be explained by considering that most airport operating companies are seen by the State as strategically relevant asset, notwithstanding their ultimate ownership. This aspect dramatically reduces their default risk, regardless of their debt level. Therefore, it is reasonable to expect the market to give a positive valuation to Airports recurring to high levels of debt, particularly when we think that bigger players may exploit a regulatory capture mechanism. This interpretation is consistent with the positive effect of Firm Size. Another counter-intuitive result, although weak in significance, regards the "Airport within $100 \mathrm{Km}$ ” dummy. Because of the likely overlapping of the catchment area, a negative coefficient was expected, while Airport valuation seems to be positively influenced by the proximity of other airports. In fact, this first-order effect is probably more than compensated by an incentive to compete, generated by the proximity of other airports. As a net effect, the presence of competitors induces the management of an airport to be more market oriented, and financial markets recognize a higher value to these firms. Multi airport is also a signal of densely populated areas.

As far as the set of Firm Country dummies are concerned, Lower-Middle Income countries are characterized by a positive coefficient: this group includes China and other neighbouring countries, whose expected passengers growth, in light of several available forecasts, among which the Global Market Forecast published by Airbus in 2007 for the twenty years to come, is higher than ten percent per year. Therefore, the growth opportunity premium is probably the reason behind the significance of this coefficient. Interestingly, the Aviation-Revenue share is reported with a negative coefficient, although the significance of this result is weak. 
Nevertheless, this is a first evidence of how the non-aviation business of airports has positive importance for valuation. Lastly, in contrast with the results on the aviation industry, shareholder concentration and ultimate owner identity are not significant.

\subsection{Airlines}

Table 5 reports the results of Tobin's Q regression on the sample of 87 airline carriers. The variables included in the model are the following: aircraft size, route frequency, route number, route length, passenger growth, alliance dummy, firm age, ownership concentration and low cost dummy. According to our sensitivity analysis testing, we include as well the interaction between route length and the low-cost dummy, that improves the fitting of the model.

\section{*** [Insert somewhere here Table 5] ***}

Interestingly, we dropped the variable Seats Number through the selection process, and this result is also robust to all the sensitivity analyses carried out. We can consider the effect of the business size (Seats Number) as disaggregated in three value drivers included in the model, according to the following definition:

Seats Number $=$ Routes $\times$ Frequency $\times$ Capacity

Where: Seats Number is the number of seats offered by an airline in a certain period of time, not included in the model, but represented by the following; Routes is the number of the operated routes; (Route) Frequency is the average number of flights on the operated routes; (Average Aircraft) Capacity is the average number of seats per flight.

When we consider this disaggregation, we notice that the business size impacts on valuation through the following drivers. First, as far as the number of routes is concerned, the estimated coefficient is negative. This result has to be related to the existing trade-off between the network coverage ratio and the profitability of the included routes. In fact, on the one hand, it is important to supply an extensive number of differentiated links at the international level to attract a sufficient number of passengers but, on the other hand, if load factors are not high enough, the higher the number of the connections, the more likely for unprofitable routes to be included. Second, with regards to frequency, the estimated coefficient, although not significant at a high confidence level, indicates that companies operating more frequent routes 
are better valued. Third, Aircraft Capacity is also a positive driver, although not strongly significant. Summarising, according to our results, companies are not generally valued in accordance to the number of seats they move, but, other things being equal, they receive a higher valuation when they operate their routes with higher frequencies, and when they employ larger aircrafts. They receive a lower valuation when they operate a higher number of routes. Notice that, by including the Load Factor into this model, we could interpret the combination of Routes $x$ Frequency $x$ Capacity $x$ Load Factor as a disaggregation of the actual number of passenger transported by an airline company. Nevertheless, the Load Factor variable is not significant in any models we tested in our sensitivity analyses.

With regards to the other industrial value drivers, the positive relevance of the passenger growth is intuitive, although the statistical significance is low; no great evidence is obtained with regards to the route length. Interestingly, the low-cost dummy shows a positive coefficient, validating the idea that low cost carriers may get a higher valuation by the financial markets than traditional airlines. To the best of our knowledge, this is the first empirical analysis that validates this hypothesis.

Further, as expected, the affiliation to an alliance produces a positive effect on airline company valuation, although the significance of this result is also weak. According to Park and Zhang (1998), this effect is due to an increase in long term traffic volume and on profitability, because of the better competitive position with respect to unallied companies. The affiliation allows Airlines to save on operating costs, and obtain a better negotiation power with suppliers. At the same time, the affiliation reduces risk exposure, increases the brand reputation, and gives a better position in the international market competition. Lastly, code-sharing agreements allow the companies in an alliance to extend their own network.

With regards to non-industry-specific variable, we find that shareholder concentration is positively associated to market value, in accord with former financial literature (La Porta et al., 2002), and with the results provided in the previous empirical analysis of the whole aviation industry. In fact, when the shareholder concentration increases, a proportional increase in the tendency to maximize firm value is also expected. Nevertheless, this effect is conditioned on the ultimate shareholder identity. Analogously to the results obtained for Airport value drivers, firm age is a negative determinant of firm valuation. In the specific case of airlines, most older companies are flag carriers, originally founded and managed directly by the state or by some authorities. 


\section{Conclusions}

In this paper we analysed the determinants of value of both airports and airlines, as main players of the aviation industries, characterized by an increasing number of listed firms in the worldwide financial markets. The analysis is based on a sample of 24 airports and 87 airlines listed on worldwide stock exchanges at the end of 2007. Our primary result is the evidence of relevant differences in the evaluation of firms belonging to the two main industry segments of aviation industry. This result is obtained both in a comprehensive analysis contrasting airports and airline valuation, and in industry-specific analyses, where their value drivers are separately investigated.

The analysis of value determinant has been carried out by regressing Tobin's Q, in the formulation of Chung and Pruitt (1994), against a set of variables representing i) financial information, ii) non-financial information, iii) ownership structure, and iv) industry-specific regressors. From the aggregate analysis of the aviation industry, we find that airports are more valued than airlines, and that the ownership structure plays a central role: a higher ownership concentration is linked to a higher market valuation, probably because of the better tendency to maximize firm value under these conditions. At the contrary, state control is perceived by the market as a negative value driver. Firm size is negative at the industry level, but shows a positive marginal contribution for airports. When we focus the analysis on the airport segment, we find that firm size, profitability and passenger growth are both positive value drivers, as well as the leverage. As far as airlines are concerned, we verified that low cost carriers receive higher valuations by the financial markets. A further industry specific drivers of valuation is the number of routes, with a negative coefficient. Lastly, firm age is negatively significant and the ownership concentration positively affects the market valuation.

Concluding, several value drivers supply interesting and counter-intuitive effects on the valuation mechanism of firms belonging to the aviation industry, showing that further research is needed on the topic, especially when a higher number of data will be available. 


\section{References}

Allayannis, G., Weston, J.P., 2001. The use of foreign currency derivatives and firm market value. Review of Financial Studies 14, 243-276.

Amir, E., Lev, B., 1996. Value-relevance of nonfinancial information: the wireless communications industry. Journal of Accounting and Economics 22, 3-30.

Bartov, E., Mohanram, P., Seethamraju, C., 2002. Valuation of internet stocks - An IPO perspective. Journal of Accounting Research 40, 321-346.

Bharadwaj, A.S., Bharadwaj, S.G.B., Konsynski, B.R., 1999. Information technology effects on firm performance measured by Tobin’s q. Management Science 45, 1008-1024.

Carter, D.A., Rogers, D.A., Simkins, B.J., 2006. Does fuel hedging make economic sense? The case of the US airline industry. Financial Management 35, 53-86.

Chandra, U., Procassini, A., Waymire, G., 1999. The use of trade association disclosures by investors and analysts: Evidence from the semiconductor industry. Contemporary Accounting Research 16, 643-670.

Chen, L., Zhao, X., 2006. On the relation between the market-to-book ratio, growth opportunity, and leverage ratio. Finance Research Letters 3, 253-266.

Chua, C.T., Eun, C.S., Lai S., 2007. Corporate valuation around the world: the effects of governance, growth, and openness. Journal of Banking \& Finance 31, 35-56.

Chung, K.H., Pruitt, S.W., 1994. A simple approximation of Tobin's q. Financial Management 23, 70-74.

Claessens, S., Djankov, S., Fan, J.P.H., Lang, L.H.P., 2002. Disentangling the incentive and entrenchment effects of large shareholdings. Journal of Finance 57, 2741-2771.

Copeland, T.E., Copeland, T., Koller, T., Murrin, J., 1996. Valuation: measuring and managing the value of companies. New York: John Wiley \& Sons Inc.

DaDalt, P.J., Donaldson, J.R., Garner, J.L., 2003. Will any q do? Firm characteristics and divergences in estimates of Tobin’s q. Journal of Financial Research 26, 535-551.

Faccio, M., Lang, L., 2002. The ultimate ownership of Western European corporations. Journal of Financial Economics 65, 365-395.

Fama, E.F., French, K.R., 1992. The cross-section of expected stock returns. Journal of Finance 47, 427-465. 
Fama, E.F., French, K.R., 1993. Common risk factors in the returns on stocks and bonds. Journal of Financial Economics 33, 3-56.

Frank, M.Z., Goyal, V.K., 2009. Capital Structure Decisions: Which Factors are Reliably Important? Financial Management, 38, 1-37.

Gou, R., Lev, B., Zhou N., 2005. The valuation of biotech IPOs. Journal of Accounting Auditing and Finance 20, 423-459.

Gupta, P.P., Kennedy, D.B., Weaver, S.W., 2006. Corporate governance scores, Tobin’s q and equity prices: evidence from Canadian capital markets. Working Paper, Lehigh University and University of Waterloo.

Hand, J.R.M., 2001. The Role of Book Income, Web Traffic, and Supply and Demand in the Pricing of U.S. Internet Stocks. European Finance Review 5, 295-314.

Hand, J.R.M., 2003a. Profits, losses and the non-linear pricing of Internet stocks. In Hand J.R.M., Lev, B., (Eds.), Intangible Assets: Values, Measures and Risks. Oxford: Oxford University Press.

Hand, J.R.M., 2003b. The market valuation of biotechnology firms and biotechnology R\&D. In McCahery, J., Renneboog, L., (Eds.), Venture capital contracting and the valuation of hightechnology firms. Oxford: Oxford University Press.

Henry, P.B., 2000. Stock market liberalization, economic reform, and emerging market equity prices. Journal of Finance 55, 529-564.

Lakonishok, J., Shleifer, A., Vishny, R. W., 1994. Contrarian Investment, Extrapolation, and Risk. Journal of Finance 49, 1541-1578.

La Porta, R., Lopez de Silanes, F., Shleifer, A., Vishny, R., 2002. Investor protection and corporate valuation. Journal of Finance 57, 1147-1170.

Lev, B., Sougiannis, T., 1996. The capitalization, amortization and value-relevance of R\&D. Journal of Accounting and Economics 21, 107-138.

Li, M.Z.F., Oum, T.H., Zhang Y., 2004. Tobin’s q and airline performance. Public Works Management \& Policy 9, 51-65.

Meoli, M., Paleari, S., Vismara, S., 2009. IPO Valuation of European Pyramidal Groups. Banking and Finance Review, forthcoming.

Morrell P.S., 1997. Airline Finance - 1st Edition. Aldershot: Ashgate. 
Park, J.H., Zhang, A. 1998. Airline alliances and partner firms' outputs. Transportation Research Part E: Logistics and Transportation Review 34, 245-255.

Pedersen, T., Thomsen, S., 2003. Ownership structure and value of the largest European firms: the importance of owner identity. Journal of Management and Governance 7, 27-55.

Purnanandam, A., Swaminathan, B., 2004. Are IPOs really underpriced? Review of Financial Studies 17, 811-848.

Rajgopal, S., Kotha, S., Venkatachalam, M. 2003. The Relevance of Traffic For Stock Prices of Internet Firms. Journal of Accounting Research 36, 37-46.

Rappaport A., 1986. Creating shareholder value: the new standard for business performance. New York: The Free Press.

Sarkis, J., Talluri, S., 2004. Performance based clustering for benchmarking of US airports. Transportation Research 38 - Part A, 329-346.

Sharpe, W.F., 1964. Capital asset prices: a theory of market equilibrium under conditions of risk. Journal of Finance 19, 425-442.

Tobin, J., 1969. A general equilibrium approach to monetary theory. Journal of Money, Credit and Banking 1, 15-29.

Tobin, J., Brainard, W., 1968. Pitfalls in financial model building. American Economic Review 59, 99-102.

Trueman, B., Wong, M.H., Zhang, X. J., 2000. The eyeballs have it: searching for the value in Internet stocks. Journal of Accounting Research 38, Supplement: Studies on Accounting Information and the Economics of the Firm, 137-162.

Vasigh, B., Haririan, M., 2003. An empirical investigation of financial and operational efficiency of private versus public airports. Journal of Air Transportation 9, 91-110.

Vasigh, B., Owens, J.M., Yoo, K.E., 2003. A price forecasting model for predicting value of commercial airports: a case of three Korean airports. International Journal of Transport Management 1, 225-236. 


\section{Figures}
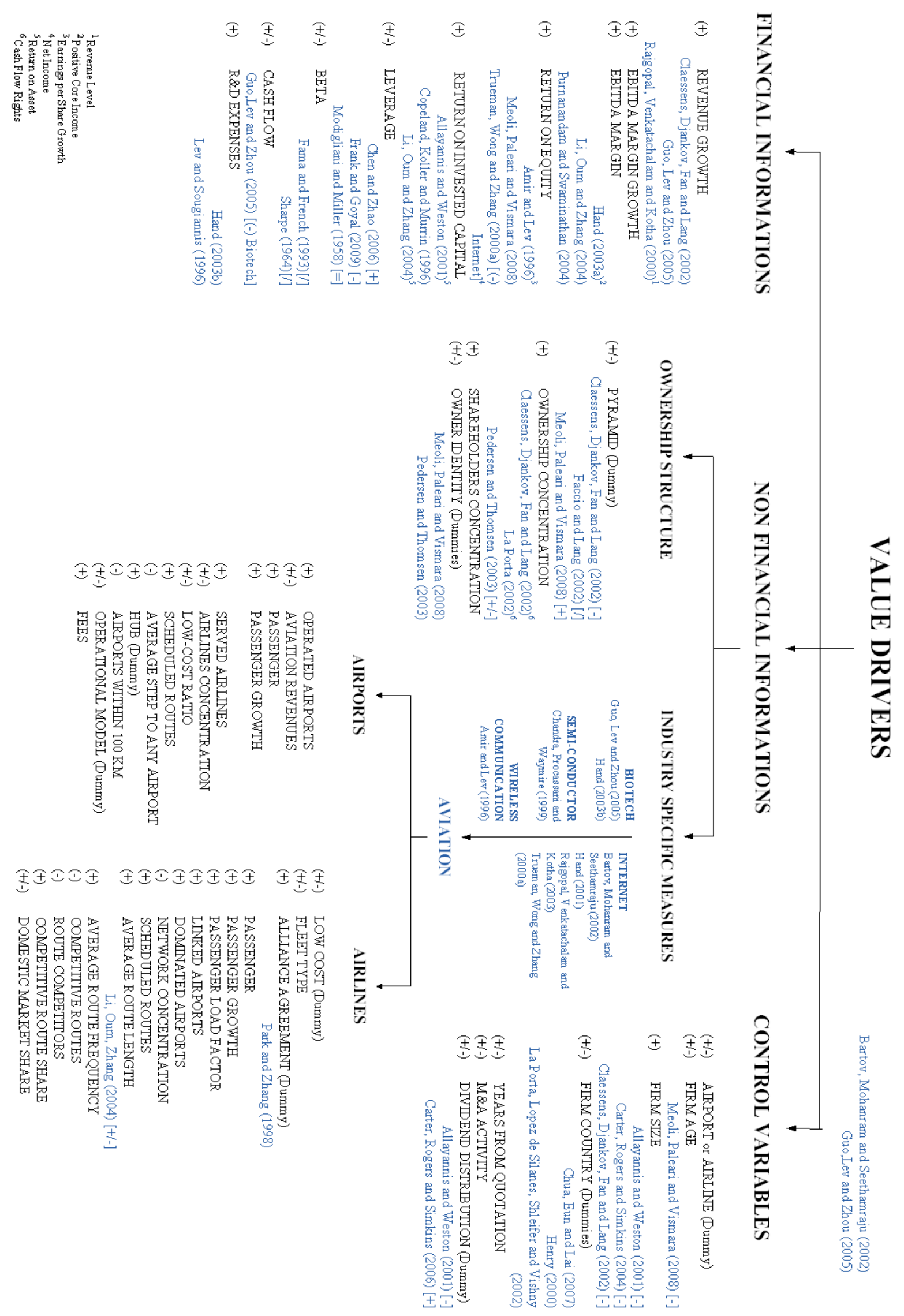

Figure 1: Table of Value drivers 


\section{Tables}

Table 1: Descriptive statistics. Valuation ratios, classified by Size quartiles

\begin{tabular}{|c|c|c|c|c|c|c|c|}
\hline & & & \multirow{2}{*}{$\begin{array}{l}\text { Full } \\
\text { sample }\end{array}$} & \multicolumn{4}{|c|}{ Classification by Size quartiles } \\
\hline & & & & Size $<\mathrm{Q}_{1}$ & $\mathrm{Q}_{1}<$ Size $<$ Median & Median $<$ Size $<Q_{3}$ & Size $>$ Q \\
\hline \multirow{9}{*}{ Airports } & \multirow{3}{*}{$\mathrm{M} / \mathrm{B}$} & Average & 2.60 & 2.87 & 3.01 & 2.83 & 1.69 \\
\hline & & & & & & & \\
\hline & & Median & 2.12 & 2.55 & 2.79 & 1.92 & 1.66 \\
\hline & \multirow{3}{*}{ Tobin’s Q } & Average & 1.65 & 1.71 & 1.71 & 2.01 & 1.18 \\
\hline & & & & & & & \\
\hline & & Median & 1.31 & 1.42 & 1.33 & 1.43 & 1.25 \\
\hline & \multirow{3}{*}{ P/EBITDA } & Average & 14.58 & 18.62 & 17.16 & 13.77 & 8.78 \\
\hline & & & & & & & \\
\hline & & Median & 12.85 & 13.82 & 16.96 & 12.85 & 6.75 \\
\hline \multirow{9}{*}{ Airlines } & \multirow{3}{*}{$\mathrm{M} / \mathrm{B}$} & Average & 1.50 & 1.03 & 1.77 & 1.72 & 1.48 \\
\hline & & & & & & & \\
\hline & & Median & 1.61 & 2.60 & 1.49 & 1.41 & 1.48 \\
\hline & \multirow{3}{*}{ Tobin’s Q } & Average & 0.69 & 0.84 & 0.66 & 0.70 & 0.58 \\
\hline & & & & & & & \\
\hline & & Median & 0.67 & 0.74 & 0.70 & 0.67 & 0.61 \\
\hline & \multirow{3}{*}{ P/EBITDA } & Average & 4.83 & 2.54 & 1.86 & 4.89 & 9.66 \\
\hline & & & & & & & \\
\hline & & Median & 2.56 & 0.06 & 0.98 & 4.56 & 8.13 \\
\hline
\end{tabular}


Table 2: Descriptive statistics of the Value Drivers included in the empirical analyses

\begin{tabular}{|c|c|c|c|c|c|c|}
\hline Analyses & Value drivers & Definition & Average & Median & Max & Min \\
\hline \multirow{3}{*}{$\begin{array}{l}\text { Aviation } \\
\text { industry }\end{array}$} & Size & $\begin{array}{l}\text { total assets (ln of total assets in the } \\
\text { regression analyses, } \mathrm{ml} € \text { ) }\end{array}$ & 3730.15 & 1493.32 & 30690.00 & 15.72 \\
\hline & $\begin{array}{l}\text { Ownership } \\
\text { Concentration }\end{array}$ & $\begin{array}{l}\text { cumulated ownership of the three } \\
\text { main shareholders }\end{array}$ & $52.34 \%$ & $51.51 \%$ & $100.00 \%$ & $7.69 \%$ \\
\hline & State Ownership & $\begin{array}{l}\text { dummy variable equal to } 1 \text { when the } \\
\text { main owner is the state or another } \\
\text { public entity } 0 \text { otherwise }\end{array}$ & 0.19 & 0.00 & 1.00 & 0.00 \\
\hline \multirow{10}{*}{ Airports } & Size & $\begin{array}{l}\text { total assets (ln of total assets in the } \\
\text { regression analyses) }\end{array}$ & 1411.86 & 1033.01 & 6836.11 & 57.17 \\
\hline & ROA & EBIT/total assets & $8.47 \%$ & $7.80 \%$ & $18.70 \%$ & $1.05 \%$ \\
\hline & Leverage & debt/total assets & $75.46 \%$ & $61.60 \%$ & $355.20 \%$ & $4.42 \%$ \\
\hline & Passenger Growth & $\begin{array}{l}\text { growth rate in terms of passenger } \\
\text { served between } 2006 \text { and } 2007\end{array}$ & $9.95 \%$ & $9.80 \%$ & $25.29 \%$ & $-7.36 \%$ \\
\hline & $\begin{array}{l}\text { Airports within } 100 \\
\mathrm{Km}\end{array}$ & $\begin{array}{l}\text { the number of airports less than } 100 \\
\mathrm{~km} \text { far from the considered airport }\end{array}$ & 2.83 & 2.50 & 8.00 & 0.00 \\
\hline & Age & Years since foundation & 28.54 & 14.50 & 84.00 & 4.00 \\
\hline & $\begin{array}{l}\text { Aviation Revenues } \\
\text { Share }\end{array}$ & $\begin{array}{l}\text { percentage share of revenues } \\
\text { coming from aviation activity }\end{array}$ & $64.43 \%$ & $68.98 \%$ & $87.94 \%$ & $28.00 \%$ \\
\hline & $\begin{array}{l}\text { Low-Medium } \\
\text { Income country }\end{array}$ & $\begin{array}{l}\text { dummy variable equal to one if the } \\
\text { airport belong to a low-middle } \\
\text { income country ( } 936 \$-3,705 \$ \text { pc) }\end{array}$ & 0.29 & 0.00 & 1.00 & 0.00 \\
\hline & $\begin{array}{l}\text { Upper-Medium } \\
\text { Income country }\end{array}$ & $\begin{array}{l}\text { dummy variable equal to one if the } \\
\text { airport belong to a low-middle } \\
\text { income country }(3,705 \$-11,455 \$ \text { pc })\end{array}$ & 0.21 & 0.00 & 1.00 & 0.00 \\
\hline & Hi Income country & $\begin{array}{l}\text { dummy variable equal to one if the } \\
\text { airport belong to a low-middle } \\
\text { income country }(11,455 \$ \text { or more } \\
\text { pc) }\end{array}$ & 0.50 & 0.50 & 1.00 & 0.00 \\
\hline \multirow{9}{*}{ Airlines } & Aircraft size & $\begin{array}{l}\text { Average size (in terms of number of } \\
\text { seats) of aircrafts in the fleet }\end{array}$ & 185.49 & 180.00 & 341.64 & 14.46 \\
\hline & Route Frequency & Average flights per week & 22.37 & 20.91 & 52.82 & 1.89 \\
\hline & Routes & Number of operated routes & 318.11 & 192.00 & 1570.00 & 2.00 \\
\hline & Route Length & $\begin{array}{l}\text { Average } \mathrm{km} \text { length of supplied } \\
\text { routes }\end{array}$ & 1882.14 & 1719.95 & 5696.67 & 242.39 \\
\hline & Passenger Growth & $\begin{array}{l}\text { growth rate in terms of passenger } \\
\text { moved between } 2006 \text { and } 2007\end{array}$ & $12.77 \%$ & $12.62 \%$ & $94.78 \%$ & $-12.03 \%$ \\
\hline & Alliance & $\begin{array}{l}\text { Dummy variable, equal to one if the } \\
\text { company is part of an alliance }\end{array}$ & 0.53 & 1.00 & 1.00 & 0.00 \\
\hline & Age & Years since foundation & 33 & 23 & 90 & 2 \\
\hline & $\begin{array}{l}\text { Ownership } \\
\text { Concentration }\end{array}$ & $\begin{array}{l}\text { cumulated ownership of the three } \\
\text { main shareholders }\end{array}$ & $49.51 \%$ & $49.62 \%$ & $100.00 \%$ & $7.69 \%$ \\
\hline & Low Cost & $\begin{array}{l}\text { Dummy variable, equal to one for } \\
\text { low cost carriers (ICCSAI } \\
\text { classification) }\end{array}$ & 0.18 & 0.00 & 1.00 & 0.00 \\
\hline
\end{tabular}


Table 3: Value determinants for the Aviation Industry

The market value for all companies classified as Airports and Airlines, employed as an input in the calculation of the Tobin's Q, is the average market value of the year. Ownership Concentration is the Shareholder Concentration, measured as cumulated ownership of the three main shareholders; State Ownership, is a dummy variable equal to 1 when the main owner is the state or another public entity 0 otherwise; Airports is a dummy variable equal to 1 in the case of Airports, and 0 in the case of Airlines ; Size is a measure of Firm Size, defined as ln of Total Assets in 2007.

\begin{tabular}{ll}
\hline Value Drivers for the Aviation Industry & $\begin{array}{l}\text { Coefficient } \\
\text { (p-values) }\end{array}$ \\
\hline Size & $\begin{array}{l}-0.076^{* *} \\
(0.028)\end{array}$ \\
Ownership Concentration & $0.459^{*}$ \\
& $(0.096)$ \\
State Ownership, dummy & $-0.304^{* *}$ \\
& $(0.041)$ \\
Airports, dummy & $0.869^{* * *}$ \\
& $(0.000)$ \\
Intercept & 1.640 \\
& $(0.003)$ \\
R - Squared & 0.407 \\
Adjusted R-Squared & 0.382
\end{tabular}


Table 4: Value determinants for the Airports

Size is the Firm Size, measured as ln of Total Assets in 2007; ROA is the Return on Assets, defined as the ration between EBIT and Total Assets; Leverage is the Financial Leverage, defined as the ration between Total Liabilities and Debt over Total Assets; Passenger Growth is measured as the growth rate in terms of passenger served between 2006 and 2007; Airports within $100 \mathrm{Km}$ is the number of airports less than $100 \mathrm{~km}$ far from the considered airport; Age is the Firm Age, and is evaluated as difference between the observation and the foundation year; Aviation Revenues Share is the share of revenues generated by the aviation business; Country dummies control for the geographical area, dividing four groups according to the Gross National Income PerCapita in 2007 according to the World Bank classification: in our sample there is no airport in Low Income countries (935\$ or less); we have airports in Low-Medium Income countries (936\$ - 3,705\$), and in UpperMedium Income countries (3,706\$ - 11,455\$); The dummy for High Income countries $(11,456$ or more) is dropped.

\begin{tabular}{|c|c|}
\hline Value drivers for the Airports & $\begin{array}{l}\text { Coefficient } \\
\text { (p-values) }\end{array}$ \\
\hline Size & $\begin{array}{l}0.703 * * \\
(0.035)\end{array}$ \\
\hline ROA & $\begin{array}{l}22.121^{* * *} \\
(0.006)\end{array}$ \\
\hline Leverage & $\begin{array}{l}2.176^{*} \\
(0.053)\end{array}$ \\
\hline Passenger Growth & $\begin{array}{l}10.079 * * \\
(0.022)\end{array}$ \\
\hline Airports within $100 \mathrm{Km}$ & $\begin{array}{l}0.129 \\
(0.148)\end{array}$ \\
\hline Age & $\begin{array}{l}-0.032 * * \\
(0.026)\end{array}$ \\
\hline Aviation Revenues Share & $\begin{array}{l}-1.139 \\
(0.366)\end{array}$ \\
\hline Low-Medium Income countries, dummy & $\begin{array}{l}0.827 \\
(0.152)\end{array}$ \\
\hline Upper-Medium Income countries, dummy & $\begin{array}{l}-1.119 \\
(0.123)\end{array}$ \\
\hline Intercept & $\begin{array}{l}-10.226^{* *} \\
(0.031)\end{array}$ \\
\hline R - Squared & 0.6987 \\
\hline Adjusted R-Squared & 0.5051 \\
\hline
\end{tabular}




\section{Table 5: Value determinants for Airlines}

Aircraft Size is defined as the average size of a company's aircraft; Route Frequency is the average number of weekly flights operated for each route; Routes is the number of Scheduled Routes supplied by a company; Route Length is the Average Route Length scheduled by a company; Passenger Growth is measured as the growth rate in terms of passenger moved between 2006 and 2007; Alliance is the Alliance Agreement variable, a dummy taking value of 1 when a company belongs to an alliance; Age is the Firm Age, and is evaluated as difference between the observation and the foundation year; Ownership Concentration is the Shareholder Concentration, measured as cumulated ownership of the three main shareholders; Low-Cost is a dummy variable identifying company with a low-cost business model; Route Length * Low Cost is the interaction between the number of scheduled routes and the Low Cost dummy.

\begin{tabular}{ll}
\hline Value drivers for Airlines & $\begin{array}{l}\text { Coefficient } \\
\text { (p-values) }\end{array}$ \\
\hline Aircraft Size & 0.001 \\
& $(0.172)$ \\
Route Frequency & 0.003 \\
& $(0.461)$ \\
Routes & $-0.001^{* *}$ \\
& $(0.049)$ \\
Route Length & -0.001 \\
Passenger Growth & $(0.139)$ \\
Alliance, dummy & 0.465 \\
Age & $(0.107)$ \\
& 0.041 \\
Ownership Concentration & $(0.656)$ \\
Lntercept & $-0.003^{*}$ \\
\hline R - Squared & $(0.072)$ \\
Adjusted R-Squared & $0.356^{* *}$ \\
& $(0.042)$ \\
& $0.616^{*}$ \\
& $(0.059)$ \\
-0.001 \\
$(0.159)$ \\
$0.485^{* *}$ \\
$(0.010)$ \\
\hline
\end{tabular}




\section{Appendix}

Table A1: Sample of airport management companies

\begin{tabular}{|c|c|c|c|c|c|}
\hline Company & Country & Exchange & Company & Country & Exchange \\
\hline $\begin{array}{l}\text { VIENNA } \quad \text { INT. } \\
\text { Airport }\end{array}$ & Austria & Vienna S.E. & $\begin{array}{l}\text { SOCIETÀ } \\
\text { AEROPORTO } \\
\text { TOSCANO }\end{array}$ & Italy & Italian S.E. \\
\hline $\begin{array}{l}\text { BEIJING CAPITAL } \\
\text { INT. Airport }\end{array}$ & China & Hong Kong S.E. & $\begin{array}{l}\text { JAPAN AIRPORT } \\
\text { TERMINAL }\end{array}$ & Japan & Tokyo S.E. \\
\hline GUANGZHOU & & & MALAYSIA & & \\
\hline $\begin{array}{l}\text { BAIYUN } \quad \text { INT. } \\
\text { Airport }\end{array}$ & China & Shanghai S.E. & $\begin{array}{l}\text { AIRPORTS } \\
\text { HOLDINGS }\end{array}$ & Malaysia & Kuala Lumpur S.E. \\
\hline $\begin{array}{l}\text { HAINAN MEILAN } \\
\text { INT. Airport }\end{array}$ & China & Hong Kong S.E. & $\begin{array}{l}\text { MALTA } \quad \text { INT. } \\
\text { Airport }\end{array}$ & Malta & Malta S.E. \\
\hline $\begin{array}{l}\text { SHANGHAI INT. } \\
\text { Airport }\end{array}$ & China & Shanghai S.E. & $\begin{array}{l}\text { GRUPO } \\
\text { AEROPORT. DEL } \\
\text { CENTRO NORTE }\end{array}$ & Mexico & Mexican S.E. \\
\hline $\begin{array}{l}\text { SHENZHEN } \\
\text { AIRPORT }\end{array}$ & China & Shenzhen S.E. & $\begin{array}{l}\text { GRUPO } \\
\text { AEROPORT. DEL } \\
\text { PACIFICO }\end{array}$ & Mexico & Mexican S.E. \\
\hline $\begin{array}{l}\text { XIAMEN INT. } \\
\text { Airport GROUP }\end{array}$ & China & Shanghai S.E. & $\begin{array}{l}\text { GRUPO } \\
\text { AEROPORT. DEL } \\
\text { SURESTE }\end{array}$ & Mexico & Mexican S.E. \\
\hline $\begin{array}{l}\text { COPENHAGEN } \\
\text { AIRPORTS }\end{array}$ & Denmark & Copenhangen S.E. & $\begin{array}{l}\text { AUCKLAND INT. } \\
\text { Airport }\end{array}$ & New Zealand & New Zealand S.E. \\
\hline $\begin{array}{l}\text { AEROPORTS DE } \\
\text { PARIS }\end{array}$ & France & Euronext Paris & $\begin{array}{l}\text { AERODROM } \\
\text { LJUBLJANA }\end{array}$ & Slovenia & Lubiana S.E. \\
\hline FRAPORT & Germany & Frankfurt S.E. & $\begin{array}{l}\text { FLUGHAFEN } \\
\text { ZURICH }\end{array}$ & Switzerland & Swiss Exchange \\
\hline $\begin{array}{l}\text { AEROPORTI DI } \\
\text { VENEZIA MARCO } \\
\text { POLO }\end{array}$ & Italy & Italian S.E. & $\begin{array}{l}\text { AIRPORTS OF } \\
\text { THAILAND }\end{array}$ & Thailand & S.E. of Thailand \\
\hline $\begin{array}{l}\text { AEROPORTO DI } \\
\text { FIRENZE }\end{array}$ & Italy & Italian S.E. & $\begin{array}{l}\text { TAV } \\
\text { HAVALIMANLAR } \\
\text { I HOLDINGS }\end{array}$ & Turkey & Istanbul S.E. \\
\hline
\end{tabular}




\begin{tabular}{|c|c|c|c|c|c|}
\hline Company & Country & Exchange & Company & Country & Exchange \\
\hline AIR ARABIA & Arab Emirates & Dubai Fin. Mark. & $\begin{array}{l}\text { DEUTSCHE } \\
\text { LUFTHANSA }\end{array}$ & Germany & Frankfurt S.E. \\
\hline QANTAS AIRWAYS & Australia & Australian S.E. & AEGEAN AIRLINES & Greece & Athens Exch. \\
\hline $\begin{array}{l}\text { REGIONAL } \\
\text { EXPRESS } \\
\text { HOLDINGS }\end{array}$ & Australia & Australian S.E. & $\begin{array}{l}\text { CATHAY PACIFIC } \\
\text { AIRWAYS }\end{array}$ & Hong Kong & Hong Kong S.E. \\
\hline $\begin{array}{ll}\text { VIRGIN } & \text { BLUE } \\
\text { HOLDINGS } & \end{array}$ & Australia & Australian S.E. & $\begin{array}{l}\text { ICELANDAIR } \\
\text { GROUP HOLDING }\end{array}$ & Iceland & Stockholm S.E. \\
\hline $\begin{array}{l}\text { AUSTRIAN } \\
\text { AIRLINES }\end{array}$ & Austria & Vienna S.E. & DECCAN AVIATION & India & Bombay S.E. \\
\hline $\begin{array}{l}\text { SKYEUROPE } \\
\text { HOLDING }\end{array}$ & Austria & Vienna S.E. & $\begin{array}{ll}\text { JET } & \text { AIRWAYS } \\
\text { (INDIA) }\end{array}$ & India & Abu Dhabi S.M. \\
\hline $\begin{array}{l}\text { GOL LINHAS } \\
\text { AEREAS INTEL. }\end{array}$ & Brazil & Sao Paulo S.E. & SPICEJET & India & Bombay S.E. \\
\hline TAM & Brazil & New York S.E. & $\begin{array}{l}\text { AER } \\
\text { GROUP }\end{array}$ & Ireland & Irish S.E. \\
\hline $\begin{array}{l}\text { VARIG - VIACAO } \\
\text { AER. RIO GRAND. }\end{array}$ & Brazil & Sao Paulo S.E. & $\begin{array}{l}\text { RYANAIR } \\
\text { HOLDINGS }\end{array}$ & Ireland & London S.E. \\
\hline $\begin{array}{l}\text { VARIG PART. EM } \\
\text { TRANS. AER. }\end{array}$ & Brazil & Sao Paulo S.E. & $\begin{array}{l}\text { KNAFAIM - ARKIA } \\
\text { HOLDINGS }\end{array}$ & Israel & Tel Aviv S.E. \\
\hline AIR CANADA & Canada & Toronto S.E. & ALITALIA & Italy & Italian S.E. \\
\hline WESTJET AIRLINES & Canada & Toronto S.E. & EUROFLY & Italy & Italian S.E. \\
\hline LAN AIRLINES & Chile & Chilian S.E. & $\begin{array}{ll}\text { ALL } & \text { NIPPON } \\
\text { AIRWAYS } & \end{array}$ & Japan & Tokyo S.E. \\
\hline AIR CHINA & China & Hong Kong S.E. & JAPAN AIRLINES & Japan & Tokyo S.E. \\
\hline $\begin{array}{l}\text { CHINA EASTERN } \\
\text { AIRLINES }\end{array}$ & China & Hong Kong S.E. & $\begin{array}{l}\text { SKYMARK } \\
\text { AIRLINES }\end{array}$ & Japan & Tokyo S.E. \\
\hline $\begin{array}{l}\text { CHINA SOUTHERN } \\
\text { AIRLINES }\end{array}$ & China & Hong Kong S.E. & KENYA AIRWAYS & Kenya & Nairobi S.E. \\
\hline HAINAN AIRLINES & China & Hong Kong S.E. & AIRASIA & Malaysia & Kuala Lumpur S.E. \\
\hline $\begin{array}{l}\text { SHANDONG } \\
\text { AIRLINES }\end{array}$ & China & Shenzhen S.E. & $\begin{array}{l}\text { MALAYSIAN } \\
\text { AIRLINE }\end{array}$ & Malaysia & Kuala Lumpur S.E. \\
\hline $\begin{array}{l}\text { SHANGHAI } \\
\text { AIRLINES }\end{array}$ & China & Shanghai S.E. & $\begin{array}{l}\text { CONSORCIO } \\
\text { AEROMEXICO }\end{array}$ & Mexico & Mexican S.E. \\
\hline $\begin{array}{ll}\text { AEROVIAS } & \text { DE } \\
\text { INTEGR. REG. } & \end{array}$ & Colombia & Colombia S.E. & AIR NEW ZEALAND & New Zealand & New Zealand S.E. \\
\hline FINNAIR & Finland & Helsinki S.E. & $\begin{array}{l}\text { NORWEGIAN AIR } \\
\text { SHUTTLE }\end{array}$ & Norway & Oslo S.E. \\
\hline AIR FRANCE - KLM & France & Euronext Paris & $\begin{array}{l}\text { PAKISTAN } \\
\text { Airlines }\end{array}$ & Pakistan & Karachi S.E. \\
\hline
\end{tabular}


Table A2:Sample of Airlines (continued)

\begin{tabular}{|c|c|c|c|c|c|}
\hline Company & Country & Exchange & Company & Country & Exchange \\
\hline COPA HOLDINGS & Panama & New York S.E. & $\begin{array}{l}\text { AIRTRAN } \\
\text { HOLDINGS }\end{array}$ & U.S.A. & New York S.E. \\
\hline AEROFLOT & Russia & Moscow S.E. & $\begin{array}{l}\text { ALASKA } \\
\text { GROUP }\end{array}$ & U.S.A. & New York S.E. \\
\hline UTAIR & Russia & Moscow S.E. & AMR & U.S.A. & New York S.E. \\
\hline $\begin{array}{l}\text { SINGAPORE } \\
\text { AIRLINES }\end{array}$ & Singapore & Singapore Exch. & $\begin{array}{l}\text { CONTINENTAL } \\
\text { AIRLINES }\end{array}$ & U.S.A. & New York S.E. \\
\hline $\begin{array}{l}\text { SKYWEST } \\
\text { AIRLINES (ADVENT } \\
\text { AIR) }\end{array}$ & Singapore & London S.E. & DELTA AIR LINES & U.S.A. & New York S.E. \\
\hline COMAIR & South Africa & Johannesburg S.E. & $\begin{array}{l}\text { EXPRESSJET } \\
\text { HOLDINGS }\end{array}$ & U.S.A. & New York S.E. \\
\hline ASIANA AIRLINES & South Korea & South Korea S.E. & $\begin{array}{l}\text { FRONTIER } \\
\text { AIRLINES } \\
\text { HOLDINGS }\end{array}$ & U.S.A. & NASDAQ \\
\hline KOREAN AIR LINES & South Korea & South Korea S.E. & $\begin{array}{ll}\text { GREAT } & \text { LAKES } \\
\text { AVIATION } & \end{array}$ & U.S.A. & NASDAQ \\
\hline IBERIA & Spain & Madrid S.E. & JETBLUE AIRWAYS & U.S.A. & NASDAQ \\
\hline VUELING AIRLINES & Spain & Madrid S.E. & MAIR HOLDINGS & U.S.A. & NASDAQ \\
\hline SAS & Sweden & Copenhangen S.E. & MESA AIR GROUP & U.S.A. & NASDAQ \\
\hline CHINA AIRLINES & Taiwan & Taiwan S.E. & $\begin{array}{l}\text { MIDWEST } \\
\text { GROUP }\end{array}$ & U.S.A. & American S.E. \\
\hline EVA AIRWAYS & Taiwan & Taiwan S.E. & $\begin{array}{l}\text { NORTHWEST } \\
\text { AIRLINES }\end{array}$ & U.S.A. & New York S.E. \\
\hline $\begin{array}{l}\text { FAR EASTERN AIR. } \\
\text { TR. (FAT) }\end{array}$ & Taiwan & Taiwan S.E. & $\begin{array}{l}\text { PINNACLE } \\
\text { AIRLINES }\end{array}$ & U.S.A. & NASDAQ \\
\hline THAI AIRWAYS & Thailand & S.E. of Thailand & $\begin{array}{l}\text { REPUBLIC } \\
\text { AIRWAYS } \\
\text { HOLDINGS }\end{array}$ & U.S.A. & NASDAQ \\
\hline $\begin{array}{l}\text { TURK } \\
\text { YOLLARI }\end{array}$ & Turkey & Istanbul S.E. & SKY WEST & U.S.A. & NASDAQ \\
\hline AIR BERLIN & U.K. & Frankfurt S.E. & $\begin{array}{l}\text { SOUTHWEST } \\
\text { AIRLINES }\end{array}$ & U.S.A. & New York S.E. \\
\hline BRITISH AIRWAYS & U.K. & London S.E. & UAL & U.S.A. & NASDAQ \\
\hline EASYJET & U.K. & London S.E. & $\begin{array}{l}\text { US } \\
\text { GROUP }\end{array}$ & U.S.A. & New York S.E. \\
\hline SILVERJET & U.K. & London S.E. & & & \\
\hline
\end{tabular}

